\title{
NITROGEN STARVATION AFFECTS BACTERIAL ADHESION TO SOIL
}

\author{
Maria Tereza Borges; Antônio Galvão Nascimento; Ulisses Nunes Rocha; Marcos Rogério Tótola*
}

Departamento de Microbiologia, Universidade Federal de Viçosa, Viçosa, MG, Brasil

Submitted: December 06, 2007; Returned to authors for corrections: March 01, 2008; Approved: May 04, 2008.

\begin{abstract}
One of the main factors limiting the bioremediation of subsoil environments based on bioaugmentation is the transport of selected microorganisms to the contaminated zones. The characterization of the physiological responses of the inoculated microorganisms to starvation, especially the evaluation of characteristics that affect the adhesion of the cells to soil particles, is fundamental to anticipate the success or failure of bioaugmentation. The objective of this study was to investigate the effect of nitrogen starvation on cell surface hydrophobicity and cell adhesion to soil particles by bacterial strains previously characterized as able to use benzene, toluene or xilenes as carbon and energy sources. The strains LBBMA 18-T (non-identified), Arthrobacter aurescens LBBMA 98, Arthrobacter oxydans LBBMA 201, and Klebsiella sp. LBBMA 204-1 were used in the experiments. Cultivation of the cells in nitrogendeficient medium caused a significant reduction of the adhesion to soil particles by all the four strains. Nitrogen starvation also reduced significantly the strength of cell adhesion to the soil particles, except for Klebsiella sp. LBBMA 204-1. Two of the four strains showed significant reduction in cell surface hydrophobicity. It is inferred that the efficiency of bacterial transport through soils might be potentially increased by nitrogen starvation.
\end{abstract}

Key-words: hydrophobicity; bacterial adhesion; nitrogen starvation

\section{INTRODUCTION}

The subsurface contamination by hydrocarbon fuels is a frequent problem that results from leaking underground storage tanks. Depending on the characteristics of the contaminants and of the contaminated soil, contamination of deeper zones, including the saturated zone, may occur. The toxic substances that compose these fuels also have the potential to eliminate many of the microbial populations found in the contaminated zones. In the worst case, the contamination may reach the aquifer, posing a serious threat to the biological systems that make use of this resource.

The natural decontamination of these areas, without anthropic intervention, generally occurs at slow rates. The rate of in situ biological decontamination can be increased by optimizing the environmental conditions that control the activity of microbial populations, so that they can be stimulated to degrade the contaminants (3). Where microbial populations able to degrade the contaminants are absent or in low numbers, this adequacy may be followed by the introduction of selected microorganisms in the contaminated zones, a technique known as bioaugmentation (3).

The efficiency of biodegradation increases with the reduction of the contaminant flow (35). It is possible to diminish the hydraulic conductivity of a porous system by stimulating the formation of biofilms $(11,15,32)$. The use of microorganisms to clog the pores is known as biobarrier, which is based on the formation of a subsurface barrier capable of controlling the percolation of the contaminants (15). The screening of microorganisms for use in bioremediation processes based on the formation of biobarriers takes into account cell surface characteristics and the biodegradation potential of the contaminants by the selected microorganisms.

To be successful, the introduction of microorganisms must be accompanied by the transport of the cells to the contaminated spots. During transport through the soil, the bacteria can lose

\footnotetext{
*Corresponding Author. Mailing address: Department of Microbiology, Federal University of Viçosa, Viçosa, Brasil. E-mail: totola@ufv.br
} 
viability due to nutrient limitation, predation, cell lysis or parasitism (9). Bacterial hydrophobicity has been cited as a criterion to select strains for injection in porous matrices, since it will determine which strain will remain suspended for a long period, facilitating its transport into the porous medium (21). Besides, the cells may adsorb to soil surfaces, making their transport difficult through a porous matrix.

Some characteristics of the cell surface interferes with cell adhesion to soil particles. According to Ling et al. (2002) (18), bacterial adsorption to solid surfaces is a complex phenomenon, which depends on the characteristics of the microorganism, the characteristics of the solid surfaces and of the liquid phase in which the bacteria are injected. Previous works also mention the hydrophobicity of the cellular surface (26), the superficial charges $(8)$ and the physiological state of the cells $(2,30)$ as factors that may affect the attachment of bacteria to surfaces.

Kim \& Fogler (1999) (16) state that once the cells are injected into the subsurface, they generally are subjected to starvation. The starvation may affect many characteristics and factors of the bacteria, such as cell size $(3,16,36)$, cell viability $(1,23)$, resistance to environmental stresses $(10,19,23,27)$, cell surface hydrophobicity $(5,29)$, cell adhesion $(8,29,34,36)$ and the transport of the bacteria through the soil $(3,29)$. Starvation can result in a significant reduction of cell size in bacteria, and sometimes leads to the formation of ultra-micro bacteria (UMB) (3). Marouga \& Kjelleberg (1996) (19) showed that bacteria survival under nutrient limitation is coupled to the expression of certain genes that enable the cells to enter into a state of induced adaptation to starvation and to resist to a variety of physical and chemical stresses. Another important effect of nutrient starvation is the reduction of cell surface hydrophobicity when bacteria are cultivated under nitrogen limitation, apart from other alterations that may result in the reduction of cell adsorption to soil surfaces (29). Cell surface charges also exert great influence on cell adhesion, and this characteristic may also be modified during nutrient starvation $(8,34)$. A decrease of cell dimension and changes in composition of cell membrane, following a long period of nutrient starvation, may equally affect cell adhesion (36). Finally, some works affirm that the adhesion influence on the transport of the cells though the soil is higher than the influence of other surface properties $(4,34)$.

The study of bacterial starvation on the efficiency of bioremediation is relevant for two main reasons: injecting starved bacteria might be a strategy to diminish bacterial adhesion to soil particles $(29,34)$ and because, during bacterial transport, these cells suffer effects of starvation with relevant consequences, such as a decrease in cell viability. In this paper, we focused on some effects of starving bacterial cells in solutions without nitrogen, specially on the survival, surface hydrophobicity and adhesion to soil particles. To predict the effects of this strategy on bacterial transport, future works must be conducted.

\section{MATERIALS AND METHODS}

\section{Microorganisms}

The microbial strains were selected amongst those pertaining to the culture collection of the Laboratory of Environmental Biotechnology and Biodiversity, BIOAGRO/ $\mathrm{DMB} / \mathrm{UFV}$, according to their growth capacity on benzene, toluene or xylenes as the only carbon sources. The microbial strains used in this work were Arthrobacter aurescens LBBMA 98, Arthrobacter oxydans LBBMA 201, Klebsiella sp. LBBMA 204-1 and LBBMA 18-T, which doesn't pertain to the library TSBA40 of Midi System (Microbial Identification, Newark, DE, USA).

\section{Cell starvation experiments}

Frozen-preserved bacterial strains were activated in R2A (28) at $150 \mathrm{rpm}$ and $30^{\circ} \mathrm{C}$ for $15 \mathrm{~h}$. The medium was removed by centrifugation at $6,100 \mathrm{X} \mathrm{G}$ for $10 \mathrm{~min}$ and the cells were washed three times in $10 \mathrm{~mL}$ of $\mathrm{NaCl} 0.85 \%$. The cells were resuspended in $\mathrm{R} 2 \mathrm{~A}$ and incubated at $150 \mathrm{rpm}$ and $30^{\circ} \mathrm{C}$ until the middle of the log phase. For starved-cells preparation, the washed cell pellet was resuspended in $\mathrm{N}$-limiting mineral medium (NLMM) containing $\left(\mathrm{g} \mathrm{L}^{-1}\right): \mathrm{Na}_{2} \mathrm{HPO}_{4}, 2.8$; yeast extract, $0.01 ; \mathrm{Ca}\left(\mathrm{NO}_{3}\right)_{2} .4 \mathrm{H}_{2} \mathrm{O}, 0.05$; ferric ammonium citrate, $0.01 ; \mathrm{MgSO}_{4} .7 \mathrm{H}_{2} \mathrm{O}, 0.02$; glucose, 15.0; $\mathrm{KH}_{2} \mathrm{PO}_{4}, 2.0$. An aliquot of cell suspension was transferred to an Erlenmeyer flask containing $150 \mathrm{~mL}$ of NLMM, and nitrogen starvation was initiated with a cell concentration equivalent to an optic density of $600 \mathrm{~nm}\left(\mathrm{OD}_{600}\right)$ of 0.4 . Cell concentration $\left(\mathrm{OD}_{600}\right)$ was monitored daily through a seven day incubation at 150 rpm and $30^{\circ} \mathrm{C}$.

\section{Cell Surface Hydrophobicity}

Cell surface hydrophobicity was determined according to Sanin et al. (2003) (29), with modifications. Suspended cells were washed three times in $\mathrm{NaCl} 0.85 \%$, after centrifugation at $6,100 \mathrm{X} \mathrm{G}$ for $10 \mathrm{~min}$. Washed cells were resuspended in PBS, the $\mathrm{OD}_{600}$ was adjusted to 0,3 and $3 \mathrm{~mL}$ aliquots were transferred to $10 \times 100 \mathrm{~mm}$ round bottom glass tubes and the initial optical density $\left(\mathrm{OD}_{1}\right)$ was measured at $600 \mathrm{~nm}$. After that, $0,3 \mathrm{~mL}$ of nhexadecane was added to the suspension and the mixture was mixed vigorously for $2 \mathrm{~min}$. After standing for $15 \mathrm{~min}$, the water phase was removed and its $\mathrm{OD}_{600}$ was measured $\left(\mathrm{OD}_{2}\right)$. The cell surface hydrophobicity was calculated as:

Hydrophobicity $(\%)=\left(1-\mathrm{OD}_{2} / \mathrm{OD}_{1}\right) \times 100$

Where: $\mathrm{OD}_{1}=$ Optical density at $600 \mathrm{~nm}$ before the addition of n-hexadecane;

$\mathrm{OD}_{2}=$ Optical density at $600 \mathrm{~nm} 15 \mathrm{~min}$ after the addition of the n-haxadecane. 


\section{Analysis of bacterial adhesion}

The soil used for the study of bacterial adhesion was collected in the Federal University of Viçosa, Brazil, at $3 \mathrm{~m}$ depth and was composed of $58 \%$ clay, $22 \%$ silt and $20 \%$ sand.

Bacterial adhesion to soil particles was evaluated by a modification of the differential centrifugation technique proposed by Ling et al. (2002) (18). Log phase non-starved cells or starved cells were centrifuged four times at $6,100 \mathrm{X} \mathrm{G}$ for $10 \mathrm{~min}$ and resuspended in $\mathrm{NaCl} 0.85 \%$. The last resuspension was prepared in a phosphate-buffered saline (PBS) and the $\mathrm{OD}_{600}$ was adjusted to the corresponding value of $10^{8} \mathrm{CFU} \mathrm{mL} \mathrm{m}^{-1}$.

In polypropylene centrifuge tubes, $6 \mathrm{~g}$ of soil and $6 \mathrm{~mL}$ of suspended cells were mixed, following a vigorous mixing for 1 $\mathrm{min}$. After five minutes, the tubes were centrifuged for $3 \mathrm{~min}$ at $48 \mathrm{~g}$, and the supernatant was collected for cell concentration analysis. To each tube, $15 \mathrm{~mL}$ of PBS were added, following a new mixing for $3 \mathrm{~min}$. The samples were centrifuged at $200 \mathrm{~g}$ during $15 \mathrm{~min}$, and the supernatant was collected for cell concentration analysis by the micro drop technique on R2A. The cells that remained attached to the soil after the first centrifugation were considered to represent both a weakly and a strongly adhered population, and those that remained adhered to the soil particles after the second centrifugation, as a population of strongly adhered cells.

The data was used to calculate the distribution coefficient, expressed as:

$\mathrm{Kd}$ tot $(\mathrm{mL} \mathrm{g}-1)=\mathrm{Cs} / \mathrm{Cw}$, where

$\mathrm{Cs}$ and $\mathrm{CW}=$ cell concentration in solid phase $\left(\mathrm{CFU} \mathrm{g}^{-1}\right)$ and in liquid $\left(\mathrm{CFU} \mathrm{ml}{ }^{-1}\right)$, respectively, and

$\mathrm{Cs}=[\mathrm{Nt}-(\mathrm{Ns})] / \mathrm{W}$

$\mathrm{CW}=(\mathrm{Ns}) / \mathrm{V}$

$\mathrm{Ns}=\mathrm{Nw}+\mathrm{N} 1$, where

$\mathrm{Nt}=$ number of cells added to the soil (CFU)

$\mathrm{Ns}=$ number of cells in the supernatant (CFU)

$\mathrm{Nw}=$ number of cells in the supernatant after the first washing (CFU)

$\mathrm{N} 1=$ number of cells in the supernatant after the second washing $(\mathrm{CFU})$

$\mathrm{W}=$ soil weight $(\mathrm{g})$

$\mathrm{V}=$ volume of liquid in the mixture $(\mathrm{mL})$.

In this study, two coefficients of distribution were calculated: $\mathrm{Kd} 1$, relative to cells weakly adhered to the soil particles and $\mathrm{Kd} 2$, relative to cells strongly adhered to the soil particles. These coefficients indicates the ratio of bacterial cells adhered to the soil particles per unit of bacterial cells that entered in suspension after each centrifugation.
The Adhesion Ration (AR) is a new variable proposed to indicate if the bacterial strain has a strong $(\mathrm{AR}>1,0)$ or weak adhesion to the soil particles $(0<\mathrm{AR} \approx 1,0)$. $\mathrm{AR}$ was calculated as:

$\mathrm{AR}=\mathrm{Kd} 2 / \mathrm{Kd} 1$

\section{Statistical Analysis}

The experiments were conducted using an entirely random design, with three replications. The data was submitted for analysis of variance and the averages were compared by the Tukey's test at $5 \%$. The correlations between superficial cell surface hydrophobicity and adhesion of bacterial cells to soil particles were evaluated by Pearson's coefficient at $10 \%$ of probability.

\section{RESULTS}

The cell concentration curves (expressed as $\ln \mathrm{OD}_{600}$ ) (Fig. 1) and the concentration of viable cells (Fig. 2) indicated distinct behavior of the bacterial strains during nitrogen restriction. The optical density $\left(\mathrm{OD}_{600}\right)$ increased for all bacterial strains during the first hours under nitrogen starvation. A. oxydans LBBMA 201 and Klebsiella sp. LBBMA 204-1 showed a sharp increase of the $\mathrm{OD}_{600}$ until approximately $10 \mathrm{~h}$ under $\mathrm{N}$-starvation, while LBBMA 18-T and A. aurescens LBBMA 98 showed a more significant increase of OD only after $40 \mathrm{~h}$ under $\mathrm{N}$-starvation.

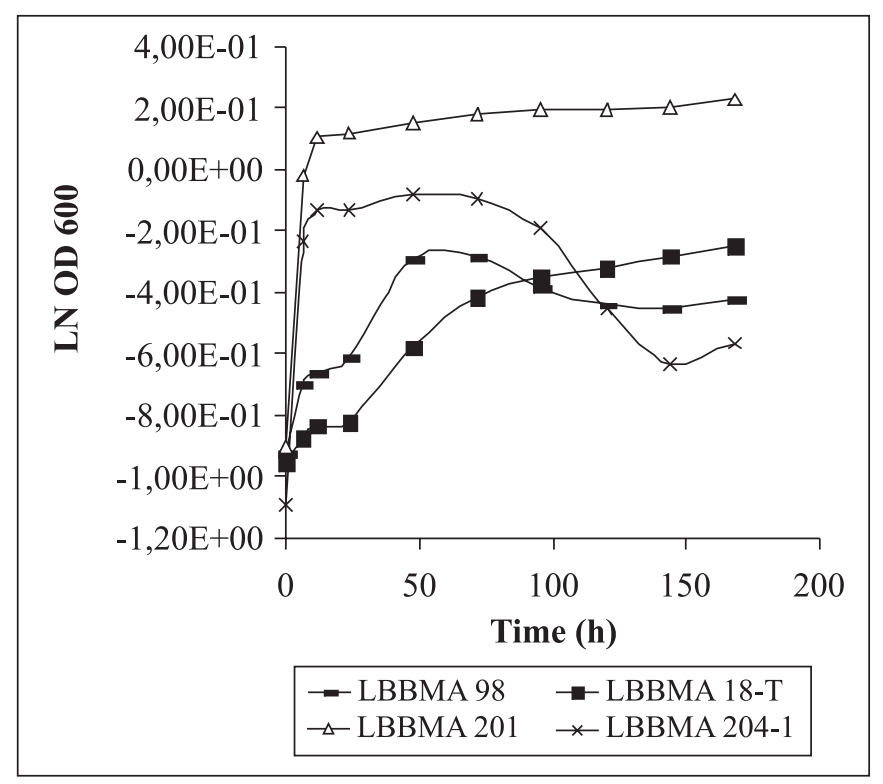

Figure 1. OD $600 \mathrm{~nm}$ during bacterial starvation in N-limiting mineral medium. LBBMA 18-T (non-identified), Arthrobacter aurescens LBBMA 98, Arthrobacter oxydans LBBMA 201, Klebsiella sp. LBBMA 204-1 


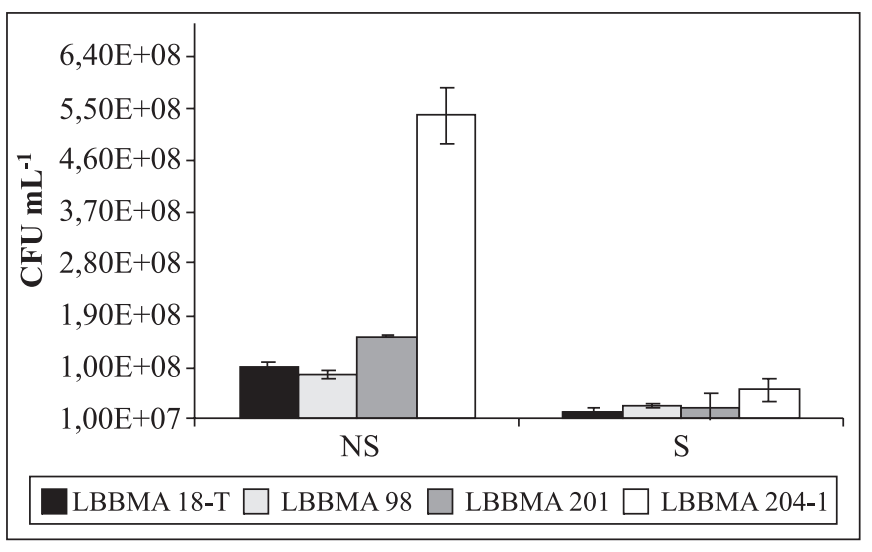

Figure 2. Concentration of viable cells $\left(\mathrm{CFU} \mathrm{mL} \mathrm{m}^{-1}\right)$ in suspensions of non-starved (NS) and of seven days nitrogenstarved cells (S). LBBMA 18-T (non-identified), Arthrobacter aurescens LBBMA 98, Arthrobacter oxydans LBBMA 201, Klebsiella sp. LBBMA 204-1

There was a significant reduction in the concentration of viable cells in suspension after 7 days of starvation, which ranged from $11 \%$ to $39 \%$ of the initial values, depending on the strain (Fig. 2).

Nitrogen starvation caused a drop in the cell surface hydrophobicity of two bacterial strains, LBBMA 18-T and Arthrobacter oxydans LBBMA 201 and a small increase in the hydrophobicity of Arthrobacter aurescens LBBMA 98. The cell surface hydrophobicity of Klebsiella sp. LBBMA 204-1 was not affected by $\mathrm{N}$-starvation (Table 1 ).

The four bacterial strains presented significant reduction of the adhesion to soil particles by the end of the seven day Nstarvation (Table 1). The largest decreases of cell adhesion were observed for LBBMA 18-T and Arthrobacter aurescens
LBBMA 98. A significant decrease of the strong to weak adhesion ratio of these strains was also evidenced (AR) after the seven day incubation under nitrogen limitation (Table 1).

Nitrogen starvation caused a reduction of the coefficient of strong adhesion to soil particles $(\mathrm{Kd} 2)$ in the four bacterial strains (Table 1). Significant change of the coefficient of weak adhesion, however, was observed only with Arthrobacter aurescens LBBMA 98 (Table 1). This demonstrates that the observed reduction of the adhesion ratio (AR) after $\mathrm{N}$-starvation (Table 1) was caused mainly by the reduction of the strong adhesion of the cells to the soil particles, and not by an increase of the weak adhesion (Table 1).

A negative correlation between the coefficients of weak and strong adhesion of non-starved cells was observed $(-0.858$, $\mathrm{p}<0.01)$. An inverse result was observed for the cells submitted to nitrogen starvation $(0.754, \mathrm{p}<0.01)$, evidencing that some important cell surface characteristics that affect the adhesion of these bacteria to soil particles might have been altered by nitrogen-starvation.

\section{DISCUSSION}

The concentration of viable cells in suspension diminished after 7 days of incubation in $\mathrm{N}$ starvation medium (Fig. 2). However, it is possible to observe an increase in the number of cells during the first hours of starvation (DO600 curves, Fig. 1), followed by the maintenance of cell concentration for some strains and decrease for others. This initial growth was probably sustained by the consumption of cell nitrogen reserves. The cells were grown initially in a rich medium (R2A), in which the bacteria may have accumulated some reserves, including nitrogen.

Nitrogen-starvation resulted in a small decrease in cell surface hydrophobicity of both strains of Arthrobacter (LBBMA 98 and LBBMA 201). No effect of N-starvation on the

Table 1. Cell surface hydrophobicity and parameters of cell adhesion to soil particles of non-starved and nitrogen-starved cells

\begin{tabular}{|c|c|c|c|c|c|c|c|c|c|c|}
\hline \multirow{2}{*}{$\begin{array}{l}\text { MICROBIAL } \\
\text { STRAIN** }\end{array}$} & \multicolumn{2}{|c|}{ HFB(\%) ${ }^{(1)}$} & \multicolumn{2}{|c|}{$\mathbf{K}_{\mathbf{d} \text { tot }}{ }^{(2)}$} & \multicolumn{2}{|c|}{$\mathbf{A R} \mathbf{R}^{(3)}$} & \multirow{2}{*}{$\begin{array}{c}\text { Kd1 } \text { ns }^{(4)} \\
\text { To }\end{array}$} & \multirow{2}{*}{$\begin{array}{c}\mathbf{K d 2} \mathbf{n s}^{(5)} \\
\text { T7 }\end{array}$} & \multirow{2}{*}{$\begin{array}{c}\mathbf{K d 1} \mathbf{s}^{(6)} \\
\text { To }\end{array}$} & \multirow{2}{*}{$\begin{array}{c}\mathbf{K d 2}{ }_{s}^{(7)} \\
\text { T7 }\end{array}$} \\
\hline & To & T7 & To & T7 & To & T7 & & & & \\
\hline LB & ונ.ד0 & $8.8 \mathrm{~B}$ & 2, & 10 & I & 3. & J & 6,367 & 6.8 & 22.5 \\
\hline LBBM & $7.4 \mathrm{~A}$ & $9.0 \mathrm{~B}$ & $5,572 \mathrm{~A}$ & $65.2 \mathrm{~B}$ & $14,954 \mathrm{~A}$ & $1.2 \mathrm{~B}$ & .1) & 17,664 & $56.1(26)$ & $68.7(3.3)$ \\
\hline LBBMA 201 & $2.5 \mathrm{~A}$ & $1.6 \mathrm{~B}$ & $43.4 \mathrm{~A}$ & $5.0 \mathrm{~B}$ & $15.3 \mathrm{~A}$ & $2.3 \mathrm{~B}$ & $4.5(0.2)$ & $67.9(6.5)$ & $3.6(0.05)$ & $8.5(3.5)$ \\
\hline LBBMA 204-1 & $0.6 \mathrm{~A}$ & $1.8 \mathrm{~A}$ & $30.6 \mathrm{~A}$ & $18.2 \mathrm{~B}$ & $14.1 \mathrm{~A}$ & $16.4 \mathrm{~A}$ & $3.7(0.7)$ & $51.9(4.0)$ & $2.3(0.6)$ & $37.9(6.2)$ \\
\hline
\end{tabular}

(1) Cell surface hydrophobicity; (2) Total adhesion coefficient; (3) Adhesion ratio (strong adhesion coefficient/ weak adhesion coefficient); (4) Kd1ns: Coefficient of distribution (Kd) related to weak adhesion of non-starved cells; (5) Kd2 ns: Coefficient of distribution (Kd) related to strong adhesion of non-starved cells; (6) Kd1 s: Coefficient of distribution (Kd) related to weak adhesion of nitrogen-starved cells; (7) Kd2 s: Coefficient of distribution $(\mathrm{Kd})$ related to strong adhesion of nitrogen-starved cells.

* Averages followed by the same letter, in the line, do not differ by Turkey's test at 5\%;

** LBBMA 18-T (non-identified), Arthrobacter aurescens LBBMA 98, Arthrobacter oxydans LBBMA 201, Klebsiella sp. LBBMA 204-1. 
hydrophobicity of Klebsiella sp LBBMA 204-1 was observed. However, the LBBMA 18-T strain showed a steep decrease of the cell surface hydrophobicity after nitrogen starvation. Sanin et al. (2002) (29) also observed a significant decrease in cell surface hydrophobicity after nitrogen starvation. On the other hand, some authors notified an increase in surface hydrophobicity of the starved cells $(31,37)$, suggesting that this effect might be specie or even strain-specific.

Jones et al. (1996) (13) defined only three groups of hydrophobicity to characterize the bacteria according to the effect of this variable on the interaction between bacterial cells and surfaces. Those authors considered cells with hydrophobicity percentage greater than $70 \%$ as highly hydrophobic; from $70 \%$ to $30 \%$ as weakly hydrophobic and those with hydrophobicity lower than $30 \%$ as highly hydrophilic (13). According to this proposal, the LBBMA 18-T strain showed significant change of cell surface hydrophobicity after Nstarvation, moving from the highly hydrophobic $(\mathrm{H}=84.5 \%)$ to the highly hydrophilic group $(\mathrm{H}=8.8 \%)$. The other bacterial strains maintained their highly hydrophilic cell surface after seven days of nitrogen restriction (Table 1).

The lack of some nutrients results in the reduction of the cell size (1,37), loss of flagella (1), modification of cell shape (37) and change in the cell surface hydrophobicity $(29,37)$, among others. Cell starvation causes changes in protein concentration at the cell membrane (5) and in the types of proteins found in the cell surface (20). Alterations of some of these characteristics can be responsible for changes in cell adhesion to surfaces (29). The cell surface hydrophobicity of some bacterial strains increased in carbon-limited medium $(29,37)$, decreased in nitrogen-limited medium $(5,29)$ and decreased slowly in PBS (12). Sanin et al. (2003) (29) argues that the excess of carbon in the nitrogen-limited medium is partially used by the bacteria for the production of extracellular carbohydrates, whose hydrophilic groups cover the bacterial surface, diminishing its hydrophobicity.

The data on cell adhesion obtained in this work allow us to infer about the potential of the transport of these bacterial isolates through the soil, since the adhesion to the solid surfaces diminishes cell transport through porous media (34). According to Camper et al. (1993) (4), the potential of microbial transport can be determined with greater accuracy by the analysis of its adhesion to glass surfaces than by the analysis of individual characteristics, such as cell dimension and motility. It is also reported that inhibition of pili formation due to starvation impairs the adherence of Myxoccocus xanthus to polystyrene surfaces (14). Strains of Rhizobium meliloti submitted to nutrient starvation showed a gradual loss of flagella and of motility (38). The rate in which non-flagellated cells adhere to and accumulate in a substratum is lower than that of cells with these structures (22). In Vibrio cholerae, a protein of the flagellum participates effectively in the process of cell adhesion (7).
The strong adhesion coefficient of bacterial cells to the soil was higher than the weak adhesion coefficient. The same result was found by Ling et al. (2002) (18) for one of the soils they used. This effect may have been caused by the ionic interaction during cell washing in $\mathrm{NaCl} 0.85 \%$ which, instead of removing the cells adhered to the soil surfaces, may have increased the strength of cell adhesion (9). However, after nitrogen starvation, there was a reduction of the coefficient of strong adhesion to soil particles. For LBBMA 18-T and Arthrobacter aurescens LBBMA 98, a decline of the strong to weak adhesion ratio was evidenced; we did not find any reference in the consulted literature that could help explain this effect of $\mathrm{N}$-starvation in the correlation between these two variables, though.

Changes in cell hydrophobicity during starvation, together with other factors, may be involved in the decreased bacterial adhesion to soil observed in this work. Oliveira et al. (2007) (25) reported that an increase in cell surface hydrophobicity would increase cell adhesion to surfaces; however, they didn't find a direct relationship between these two variables. In this study, we did not observe the existence of significant correlation between cell hydrophobicity and adhesion in non-starved cells, suggesting the existence of other factors more relevant for bacterial adhesion to soil particles. However, a significant correlation between hydrophobicity and cell adhesion to soil was found in nitrogen-starved cells $(0.639, p<0.05)$ It must be emphasized, however, that the existence of a significant correlation does not mean necessarily the existence of a direct relationship between the variables (24), which lead us to conclude that those variables may not present a cause-effect relationship, but instead may have been modified in a similar way in response to nitrogen starvation. Studies with bacterial species like Staphylococcus aureus, Listeria monocytogenes, and Lactobacillus sp. indicate the existence of a positive relationship between cell hydrophobicity and adhesion $(6,8,33)$, while others did not show a correlation between these two variables $(9,25,31)$.

The evaluation of the response of bacteria to nutrient starvation has implications on the efficiency of bioaugmentation operations, since a significant loss of cell viability can occur during transport of the cells trough the soil matrix. Conditioning the microbial strains to nutrient scarcity and studying their response to starvation may allow screening for those that can adapt and survive for long periods under this condition, and if the starved cells can resume growth after environmental factors become favorable (1). The microbial survival after introduction into the soil is affected by the physiological state of the cells, and it is possible to improve the efficacy of microbial agents after their application in the environment by using small starvation periods (38). Besides, bacteria submitted to small periods of starvation are more efficient in degrading toxic compounds than the same bacteria grown in a rich medium (17).

Data from this study suggest that nitrogen-starvation may help to diminish the adhesion of bacterial cells to soil particles. 
Studies of cell transport through soil will help to elucidate the correlation between cell surface characteristics, adhesion and cell transport efficiency.

\section{ACKNOWLEDGMENTS}

The authors would like to thank the financial support of this study by the National Counsel of Technological and Scientific Development (CNPq) and CTPETRO grant ref. 1290/00 (FINEP), The Brazilian Innovation Agency Agreement 65.00.037.00.

\section{RESUMO}

\section{Adesão de bactérias desnutridas por nitrogênio a solo}

Um dos principais fatores limitantes da biorremediação in situ de solos subterrâneos, baseada na bioaumentação, é o transporte dos microrganismos selecionados até o local contaminado. A caracterização das respostas físiológicas dos microrganismos introduzidos no subsolo a condições de escassez nutricional, notadamente a avaliação de características que afetam a adesão celular ao solo, é fundamental para se prever o sucesso da bioaumentação. O objetivo deste trabalho foi determinar o efeito da desnutrição em meio com escassez de nitrogênio sobre a hidrofobicidade celular e a adesão ao solo de quatro isolados bacterianos previamente caracterizados como capazes de utilizar benzeno, tolueno ou xileno como fonte de carbono e energia. As linhagens LBBMA 18-T (não identificada), Arthrobacter aurescens LBBMA 98, Arthrobacter oxydans LBBMA 201, and Klebsiella sp. LBBMA 204-1 foram utilizadas nos experimentos. O cultivo das células em meio deficiente em nitrogênio causou uma redução significante na força de adesão das células às partículas do solo, exceto para a Klebsiella sp. LBBMA 204-1. Dois dos quatro isolados estudados sofreram alteração significativa na hidrofobicidade celular. Os resultados sugerem que a eficiência do transporte bacteriano através do solo pode ser aumentada pela desnutrição celular.

Palavras chave: Hidrofobicidade; adesão bacteriana; desnutrição por nitrogênio

\section{REFERENCES}

1 Amy, P.S.; Morita R.Y. (1953). Starvation-survival patterns of sixteen freshly isolated open-ocean bacteria. Appl. Environ. Microbiol., 45, 1109-1115.

2. Bruinsma, G.M.; Rustema-Abbing, M.; Van Der Mei, H.C.; Busscher, H.J. (2001). Effects of cell surface damage on surface properties and adhesion of Pseudomonas aeruginosa. J. Microbiol. Methods, 45, 95-101.

3. Bryers, J.D.; Sanin, S. (1994). Resuscitation of Starved Ultramicrobacteria to Improve in Situ Bioremediation. Ann. N.Y. Acad. Sci., 745: p.61-76.

4. Camper, A.K.; Hayes, J.T.; Sturman, P.J.; Jones, W.L.; Cunningham, A.B. (1993). Effects of motility and adsorption rate coefficient on transport of bacteria though saturates porous media. Appl. Environ. Microbiol., 59, 3455-3462.

5. Castellanos, T.; Ascencio, F.; Bashany, Y. Starvation-induced changes in the cell surface of Azospirillum lipoferum. FEMS Microbiol. Ecol., $33,0-9$.

6. Cunliffe, D.; Smart, C.A.; Alexander C.; Vulfson, N. (1999). Bacterial adhesion at synthetic surfaces. Appl. Environ. Microbiol., 65, 49955002 .

7. Deflaun, M.F.; Marshall, B.M.; Kulle, E.P.; Levy, S.B. (1994). Tn5 insertion mutants of Pseudomonas fluorencens defective in adhesion to soil and seeds. Appl. Environ. Microbiol., 60, 2637-2642.

8. Dickson, J.S.; Koohmaraie, M. (1989). Cell surface charge characteristics and their relationship to bacterial attachment to meat surfaces. Appl. Environ. Microbiol., 55, 832-836.

9. Gannon, J.; Tan, Y.; Baveye, P.; Alexander, M. (1991). Effect of sodium chloride on transport of bacteria in a saturated aquifer material. Appl. Environ. Microbiol., 57, 2497-2501.

10. Givskov, M.; Eberl, L.; Moller, S.; Poulsen, L.K.; Molin, S. (1994). Responses to Nutrient Starvation in Pseudomonas putida KT2442: Analysis of General Cross-Protection, Cell Shape, and Macromolecular Content. J. Bacreriol., 176, 7-14.

11. Hill, D.H.; Sleep, B.E. (2002). Effects of biofilm growth on flow and transport though a glass parallel plate fracture. J. Cont. Hydrol., 56, 227-246.

12. Jana, T.K.; Srivastava, A.K.; Csery, K.; Arora, D.K. (1983). Influence of growth and enviromental conditions on cell surface hydrophobicity of Pseudomonas fluorenscens in non-specific adhesion. Can. J. Microbiol., 46, 1066-1072.

13. Jones, D.S.; Adair, C.G.; Mawhinney, W.M.; Gorman, S.P. (1996). Standardisation and comparison of methods employed for microbial cell surface hydrophobicity and charge determination. Int. J. Pharm., $131,83-89$.

14. Kaiser, D. (2000). Bacterial motility: How do pili pull? Curr. Biol., $10,777-780$

15. Kim, G. (2004). Hydraulic conductivity change of bio-barrier formed in the subsurface by the adverse conditions including freeze - thaw cycles. Cold Reg. Sci. Technol., 38, 153-164.

16. Kim, D.S.; Fogler, H.S. (1999). The effects of exopolymers on cell morphology and culturability of Leuconostoc mesenteroides during starvation. Appl. Microbiol. Biotechnol., 52, 839-844.

17. Leung, K.T.; Moore, M.; Lee, H.; Trevors, J.T. (2005). Effect of carbon starvation on p-nitrophenol degradation by a Moraxella strain in buffer and river water. FEMS Microbiol. Ecol., 51, 237245.

18. Ling, T.Y.; Achberger, E.C.; Drapcho, C.M.; Bengtson, R.L. (2002). Quantifying adsorption of an indicator bacteria in soil-water system. Transactions of the American Society of Agricultural Engineers., 45, 669-674.

19. Marouga, R.; Kjelleberg, S. (1996). Synthesis of immediate upshift (lup) proteins during recovery of marine Vibrio sp. Strain S14 subjected to long-term carbon starvation. J. Bacteriol., 178, 817-822.

20. Matin, A. (1990). Molecular analysis of the starvation stress in Escherichia coli. FEMS Microbiol. Ecol., 74 (2-3), 185-196.

21. Mehmannavaz, R.; Prasher, S.O.; Ahmad, D. (2001). Cell surface properties of rhizobial strains isolated from soils contaminated with hydrocarbons: hydrophobicity and adhesion to sandy soil. Process Biochem., 36, 683-688.

22. Meuller, R.F. (1996). Bacterial transport and colonization in low nutrient environments. Pergamon., 30, 2681-2690.

23. Nelson, D.R.; Sadlowski, Y.; Eguchi, M.; Kjelleberg, S. (1997). The starvation-stress response of Vibrio (Listonella) anguillarum. Microbiol., 143, 2305-2312.

24. Neter, J.; Wasserman, W.; Kutner, M.H. (1990). Applied linear statistical models: regression, analysis of variance, and experimental designs. p. 1181. 
25. Oliveira, K.; Oliveira, T.; Teixeira, P.; Azeredo, J.; Oliveira, R. (2007). Adhesion of Salmonella Enteritidis to stainless steel surfaces. Braz. J. Microbiol., 38, 318-323.

26. Peng, Jui-Sen, Tsai, Wei-Chong, Chou, Cheng-Chun. (2001). Surface characteristics of Bacillus cereus and its adhesion to stainless steel. Int. J. Food Microbiol., 65, 105-111.

27. Pichereau, V.; Hartke, A.; Auffray, Y. (2000). Starvation and osmotic stress induced multiresistances influence of extracellular compounds. Int. J. Food Microbiol., 55, 19-25.

28. Reasoner, D.J.; Geldreich, E.E. (1985). A new medium for the enumeration and subculture of bacteria from potable water. Appl. Environ. Microbiol., 49 (1) 1-7.

29. Sanin, S.L.; Sanin, F.D.; Bryers, J.D. (2003). Effect of starvation on the adhesive properties of xenobiotic degrading bacteria. Process Biochem., 38, 909-914.

30. Smets, B.F.; Grasso, D.; Engwall, M.A.; Machinist, B.J. (1999). Surface physicochemical properties of Pseudomonas fluorescens and impact on adhesion and transport though porous media. Coll surf., 14, 121139.

31. Sorogon, M.L.; Bloocgood, R.A.; Burchard, R.P. (1991). Hydrophobicity, Adhesion, and Surface-Exposed Proteins of Gliding Bacteria. Appl. Environ. Microbiol., 57, 3193-3199.
32. Thullner, M.; Schroth, M.H.; Zeyer, J.; Kinzelbach, W. (2004). Modeling of a microbial growth experiment with bioclogging in a two-dimensional saturated porous media flow field. J. Contam. Hydrol., 70, 37-62.

33. Vadillo-Rodríguez, V.; Busscher H.J.; Van Der Mei, H.C.; Vries, J.; Norde, W. (2005). Role of lactobacillus cell surface hydrophobicity as probed by AFM in adhesion to surfaces at low and high ionic strength. Coll. Surf B., 41, 33-41.

34. Van Schie, P.M.; Fletcher, M. (1999). Adhesion of biodegradative anaerobic bacteria to solid surfaces. Appl. Environ. Microbiol., 65 , 5082-5088.

35. Vaywnas, D.V.; Michalopoulou, E.; Constantinides, G.N.; Pavlou, S.; Payatakes, A.C. (2002). Visualization experiments of biodegradation in porous media and calculation of the biodegradation rate. $A d v$. Water Res., 25, 203-219.

36. Wanner, U.; Egli, T. (1990). Dynamies of microbial growth and cell composition in batch culture. FEMS Microbiol., 75, 19-44.

37. Watanabe, K.; Miyashita, M.; Harayama, S. (2000). Starvation improves survival of bacteria introduced into activated sludge. Appl. Environ. Microbiol., 66, 3905-3910.

38. Wei, X.; Bauer, W. (1998). Starvation-induced changes in motility, chemotaxis, and flagellation of rhizobium meliloti. Appl. Environ. Microbiol., 64, 1708-1714. 